\title{
PENGEMBANGAN INSTRUMEN SOAL HOTS MATEMATIKA TINGKAT SMA/SMK UNTUK MENUNJANG KEMAMPUAN LITERASI MATEMATIS
}

\author{
Dedi Nur Aristiyo ${ }^{1)}$, Ida Yuniar Triastuti ${ }^{2)}$, Eka Farida Fasha ${ }^{3)}$ \\ ${ }^{1,3)}$ Pendidikan Matematika Universitas Peradaban, ${ }^{2)}$ SMA N 1 Paguyangan \\ 1)dedinuraristiyo@gmail.com, ${ }^{2)}$ idayuniartryastuti@gmail.com, ${ }^{3)}$ efaridafasha@gmail.com
}

\begin{abstract}
Received:

08/12/2020

This research is a development research with the aim of obtaining a valid and feasible HOTS question instrument. The instrument for HOTS questions was developed for both high school and vocational high school levels. The research

Accepted :

08/12/2020 method used is research and development / known as R\&D (research and development). The model used by Borg \& Gall's R\&D. which includes the stages: Preliminary Study, Product Development, and Product Testing. From the question instrument developed, it meets the valid criteria and is very valid in each category.

Published :

21/01/2021 In other words, the instrument for HOTS questions developed can be declared valid and usable.
\end{abstract}

Keywords: Question Instruments, HOTS, Mathematics

\begin{abstract}
Abstrak
Penelitian ini merupakan penelitian pengembangan dengan tujuan mendapatkan instrument soal HOTS yang valid dan layak digunakan. Instrument soal HOTS yang dikembangkan untuk tingkat sekolah menengah baik SMA/SMK. Metode penelitian yang digunakan adalah penelitian dan pengembangan/dikenal dengan R\&D (research and development). Model yang digunakan R\&D Borg \& Gall. yang meliputi tahapan: Studi Pendahuluan, Pengembangan produk, dan Uji Produk. Dari instrument soal yang dikembangkan memenuhi kriteria valid dan sangat valid pada masing-masing kategori. Dengan kata lain instrument soal HOTS yang dikembangkan dapat dinyatakan valid dan dapat digunakan.
\end{abstract}

Kata Kunci: Instrumen Soal, HOTS, Matematika.

\section{Pendahuluan}

Dunia pendidikan, terutama pendidikan di sekolah, matematika merupakan salah satu mata pelajaran yang sangat penting karena matematika merupakan ilmu yang diajarkan disetiap jenjang pendidikan. Dalam pembelajaran matematika peserta didik dituntut untuk mengembangkan kemampuan matematiknya berdasarkan pengetahuan atau pengalaman peserta didik untuk meningkatkan kemampuan literasi matematika.

Literasi matematika adalah kecakapan individu untuk memformulasi, menggunakan dan menjelaskan matematika dalam berbagai konteks. Termasuk didalamnya penalaran matematik dan menggunakan konsep, prosedur, fakta dan alat-alat matematika untuk mendeskripsikan, menjelaskan dan memprediksi suatu kejadian. Hal inilah yang memandu individu untuk mengenali peran matematika dalam kehidupan dan membuat penilaian yang baik serta pengambilan keputusan yang bersifat membangun dan reflektif. Literasi matematika siswa Indonesia masih rendah hal ini dilihat dari hasil Survey yang 
dilakukan oleh Organisation for Economic Cooperation and Development (OECD) menggunakan tes Programme Internationale for Student Assesment (PISA) tahun 2015, pendidikan di Indonesia menduduki ranking 69 dari 76 negara yang mengikuti tes PISA. Salah satu faktor yang menyebabkan kemampuan berpikirnya masih rendah adalah kurang terlatihnya anak Indonesia dalam meyelesaikan tes atau soal soal yang sifatnya menuntut analisis, evaluasi, dan kreativitas yang tinggi. Soal-soal yang memiliki karakteristik tersebut adalah soal-soal untuk mengukur HOTS (Dewi, 2016).

Cross dalam Sukardi (2012: 1) menyatakan evaluasi merupakan proses yang menentukan kondisi, dimana suatu tujuan telah dapat dicapai. Arifin (2012: 6), evaluasi merupakan salah satu komponen penting dan tahap yang harus ditempuh oleh guru untuk mengetahui keefektivan pembelajaran. Evaluasi merupakan kegiatan yang dilakukan terus menerus dan sistematis sehingga dapat menggabrkan ketercapaian kemampuan siswa yang ditargetkan.

Muliyani dan Huriyati (2016), menyatakan evaluasi dapat dilakukan dengan instrument tes maupun non tes. Instrumen bentuk tes adalah pertanyaan secara tertulis yang disusun sesuai kaidah penyusunan tes yang benar, sedangkan instrumen bentuk nontes contohnya wawancara, pengamatan, penyebaran angket untuk mengukur suatu aspek tertentu pada siswa. Mardapi (2012: 179), ada dua acuan yang digunakan dalam menyiapkan tes dan menafsirkan hasil tes, yaitu acuan norma dan acuan kriteria. Kedua acuan ini menggunakan asumsi yang berbeda tentang kemampuan seseorang.

Crocker dan Algina dalam Purwanto (2013: 99), tingkat kesukaran atau (difficulty index) atau disingkat TK didefinisikan sebagai proporsi siswa yang menjawab benar. Aiken dalam Wahidmurni, dkk (2010: 131), mendefinisikan, Tingkat kesukaran soal adalah peluang untuk menjawab benar suatu soal pada tingkat kemampuan tertentu. Wahidmurni, dkk (2010: 134), menyatakan, daya pembeda soal adalah kemampuan suatu butir soal dapat membedakan antara siswa yang telah menguasai materi yang ditanyakan dan siswa yang tidak/kurang/belum menguasai materi yang ditanyakan. Sedangkan pengecoh (distractor) adalah pilihan jawaban yang bukan merupakan kunci jawaban.

Heong, dkk (2011) kemampuan berpikir tingkat tinggi didefinisikan sebagai penggunaan pikiran secara luas untuk menemukan tantangan baru. Kemampuan berpikir tingkat tinggi ini menghendaki seseorang untuk menerapkan informasi baru atau pengetahuan sebelumnya dan memanipulasi informasi untuk menjangkau kemungkinan jawaban dalam situasi yang baru. Woolfolk (2008), menyatakan peserta didik yang memiliki keterampilan berfikir tingkat tinggi mampu membedakan antara fakta dan opini, 
mengidentifikasi informasi yang relevan, memecahkan masalah, dan mampu menyimpulkan informasi yang telah dianalisisnya. Dari uraian yang telah dijelaskan beberapa ahli, maka dapat disimpulkan bahwa kemampuan berpikir tingkat tinggi adalah kemampuan berpiki yang menuntut seseorang untuk mengelola informasi baru ataupun pengetahuan sebelumnya dan memanipulasi informasi yang ada dengan cara tertentu sehingga memberikan mereka pengertian dan implikasi baru. Menurut Uno (2012), soal HOTS memiliki empat indikator, yaitu:

a. Problem solving atau proses dalam menemukan masalah serta cara memecahkan masalah berdasarkan informasi yang nyata, sehingga dapat ditarik kesimpulan.

b. Keterampilan pengambilan keputusan, yaitu ketrampilan seseorang dalam memecahan masalah melalui pengumpulan informasi untuk kemudian memilih keputusan terbaik dalam memecahkan masalah.

c. Keterampilan berpikir kritis adalah usaha untuk mencari informasi yang akurat yang digunakan sebagiamana mestinya pada suatu masalah.

d. Keterampilan berpikir kreatif, artinya menghasilkan banyak ide sehingga menghasilkan inovasi baru untuk memecahkan masalah.

Dalam perkembangan taksonomi Bloom yang telah direvisi oleh Krathworl dan Andrerson, (2015) remembering (C1), understanding(C2), applying(C3) dikategorikan dalam Lower order thinking skills (LOTS), sedangkan analyzing(C4), evaluating(C5) dan creating(C6) dikategorikan dalam Higher Order Thinking Skills (HOTS).

Literasi matematika menurut Abidin dkk. (2017: 7-8) adalah kemampuan individu untuk menformulasikan, membangun dan menginterpretasikan matematika dalam berbagai konteks. Termasuk juga penggunaan matematika dalam segala segi kehidupan (Asmara dkk. 2017: 135), sedangkan literasi matematika diartikan oleh Sari (2015: 713) sebagai kemampuan siswa dalam matematika yang tidak hanya sekedar kemampuan dalam berhitung saja, akan tetapi kemampuan bernalar yang logis dan kritis dalam pemecahan masalah yang tidak semata-mata hanya masalah yang berupa soal rutin tetapi lebih kepada permasalahan yang dihadapi sehari-hari. Sejalan dengan OECD (2014: 37), dimana literasi matematika merupakan kemampuan individu untuk merumuskan, menerapkan, dan menafsirkan matematika dalam berbagai konteks, yang mencakup penalaran matematis dan kemampuan menggunakan konsep-konsep matematika, prosedur, fakta dan fungsi matematika, menggambarkan, menjelaskan dan memprediksi suatu fenomena. Ciri-ciri seorang individu yang memiliki kemampuan literasi yang baik 
yaitu mampu memahami dan membaca grafik, tabel, diagram, menginterpretasikan kemampuan matematis dalam kehidupan sehari-hari dalam berbagai konteks (Pamungkas, 2017: 229).

Soal-soal Higher Order Thinking Skill (HOTS) merupakan instrumen pengukuran yang digunakan untuk mengukur kemampuan berpikir tingkat tinggi, yaitu kemampuan berpikir yang tidak sekadar mengingat (recall), menyatakan kembali (restate), atau merujuk tanpa melakukan pengolahan (recite). Soal-soal HOTS pada konteks asesmen mengukur kemampuan: 1) transfer satu konsep ke konsep lainnya, 2) memproses dan menerapkan informasi, 3) mencari kaitan dari berbagai informasi yang berbeda-beda, 4) menggunakan informasi untuk menyelesaikan masalah, dan 5) menelaah ide dan informasi secara kritis (Kemendikbud: 2018). Soal tipe HOTS mulai dikembangkan oleh pemerintah pada tahun 2013/2014 khususnya untuk Ujian Nasional (UN) mata pelajaran Matematika tingkat SMP, memuat soal HOTS berupa soal olimpiade internasiona sebanyak 5\% dari 40 soal UN matematika.

Menteri Pendidikan dan Kebudayaan (Mendikbud) Muhdjir Effendy menyatakan sebagian soal UN 2018 memakai standar Higher Order Thingking Skills (HOTS), dari total jumlah soal yang diujikan sekitar 10\% sampai 15\% memerlukan jawaban dengan daya nalar tingkat tinggi. Dari hal ini diperkirakan setiap tahun presentase soal UN dengan tipe HOTS akan terus meningkat. Hal ini salah satu yang mendasari guru untuk membuat atau mengembangkan instrument HOTS. Permasalahan dalam penelitian ini yaitu bagaimana menghasilkan instrument soal HOTS yang dapat menunjang literasi matematis siswa. Tujuannya menghasilkan instrument soal HOTS yang valid, dimana dapat digunakan untuk pembelajaran di sekolah sehingga dapat menunjang literasi matematis siswa.

\section{Metode Penelitian}

Metode penelitian yang digunakan adalah penelitian dan pengembangan/dikenal dengan R\&D (research and development). Model yang digunakan R\&D Borg \& Gall. yang meliputi tahapan: Studi Pendahuluan, Pengembangan produk, dan Uji Produk (Sukmadinata, 2013). Produk yang dihasilkan pada penelitian ini yaitu instrument soal HOTS matematika tingkat SMA/SMK dengan tahap penelitian yang akan dilakukan sebagai berikut.

a. Tahap Studi Pendahuluan 
Tahap ini merupakan kegiatan mempersiapkan produk yang akan dikembangankan dengan melakukan studi pendahuluan untuk memperoleh informasi kebutuhan. Tahap ini meliputi studi pustaka dan wawancara.

b. Tahap Perencanaan

Tahap ini dilakukan analisis kurikulum untuk menentukkan isi satuan pelajaran/materi yang meliputi analisis struktur isi, analisis pemetaan materi dan konsep serta analisis tujuan pembelajaran.

c. Penyusunan Draf instrument soal HOTS

Penyusunan draf instrument soal HOTS yang akan digunakan dalam penelitian pengembangan ini meliputi :

a. Penyusunan instrument dengan menyesuaikan materi matematika tingkat SMA/SMK.

b. Penyusunan instrument menyesuaikan dengan standar kompetnsi dan indikator ketercapaian dari materi tersebut

c. Penyusunan instrument dengan acuan indikator HOTS, yaitu mencapai level C4, C5, dan C6.

d. Tahap Pengembangan (Validasi Produk dan Revisi )

Tahap validasi konstruk. Draf instrument soal HOTS ini dilakukan penilaian oleh ahli materi, teman sejawat, dan guru. Melakukan uji coba instrument soal untuk melihat reliabilitas, daya beda, dan tingkat kesukaran. Dikarenakan masa pandemi uji coba dilakukan secara terbatas dan hanya mengambil sampel soal dimasingmasing materi. Hasil penilaian validator digunakan untuk melakukan revisi. Revisi dilakukan dengan memperhatikan saran yang diberikan oleh validator. Penetapan kelayakan dan kevalidan produk yang dikembangkan berdasarkan tahapan berikut (Fithriyah, 2018).

1) Mencari rata-rata dari setiap kategori

$$
R K_{i}=\frac{\sum_{j=1}^{n} V_{i j}}{n}
$$

\section{Keterangan:}

$R K_{i} \quad=$ Rata-rata kategori- $i$

$V_{i j}=$ Skor hasil penliaian validator ke-j terhadap kategori ke- $i$

$n \quad=$ Banyaknya validator

2) Mencari rata-rata pada tiap aspek dari semua validator 


\section{$\underline{94}$} Vol. 9 No. 1 Januari 2021 hal. $89-98$

$$
R A_{i}=\frac{\sum_{j=1}^{n} R K_{i j}}{n}
$$

\section{Keterangan:}

$$
\begin{array}{ll}
R A_{i} & =\text { Rata-rata aspek- } i \\
R K_{i j} & =\text { Skor hasil kategori ke-j terhadap aspek ke- } i \\
n & =\text { Banyaknya kategori dalam aspek ke- } i
\end{array}
$$

3) Mencari rata-rata total validitas

$$
V R=\frac{\sum_{i=1}^{n} R A_{i}}{n}
$$

\section{Keterangan:}

$$
\begin{array}{ll}
V R & =\text { Rata-rata total validitas } \\
R A_{i} & =\text { Rata-rata aspek ke- } i \\
n & =\text { Banyaknya aspek }
\end{array}
$$

Penetapan kelayakan dan kevalidan produk yang dikembangkan dimana instrument soal HOTS ditetapkan valid dan layak digunakan sesuai pada tabel 1 (Fithryah, 2018).

Tabel 1. Kriteria Pengkategorian Kevalidan

\begin{tabular}{ll}
\hline Interval Skor & \multicolumn{1}{c}{ Kategosi Kevalidan } \\
\hline $4 \leq V R \leq 5$ & Sangat Valid \\
$3 \leq V R<4$ & Valid \\
$2 \leq V R<3$ & Kurang Valid \\
$1 \leq V R<2$ & Tidak Valid \\
\hline
\end{tabular}

\section{Hasil dan Pembahasan}

Penelitian ini merupakan penelitian pengembangan dengan tujuan mendapatkab instrument soal HOTS yang valid dan layak digunakan. Instrument soal HOTS yang dikembangkan untuk tingkat sekolah menengah baik SMA/SMK. Dalam pengembangan instrument soal dilakukan beberapa tahapan.

Tahap studi pendahuluan dilakukan analisis kebutuhan dengan melakukan studi Pustaka dan wawancara kepada guru matematika guna, dari kegiatan tersenut dihasilkan informasi bahwasannya selama ini masih kurang tersedia instrument soal-soal HOTS untuk matapelajaran matematika. Kemampuan siswa dalam menyelesaikan permasalahan HOTS masih rendah, bahkan isu nasional tentang kemampuan siswa menyelesaika soal HOTS juga rendah. Kemendikbud (2018) merilis capaian Nilai Ujian Nasional SMA/MA mata pelajaran Matematika, secara umum rata-rata nilai UN matematika tahun 2018 
menurun daripada tahun-tahun sebelumnya, dimana pada UN tersebut diberikan beberapa soal - soal HOTS.

Tahap rancangan produk yaitu instrument soal HOTS matematika yang dirancang atas dasar hasil studi Pustaka. Beberapa materi yang akan dibuat instrument soal disesuaikan dengan kurikulum matematika pada kurikulum 2013. Instrument soal yang dibuat mengacu pada kriteria HOTS yaitu level C4, C5 dan C6 sesuai pengkategorian taksonomi Blomm. Produk Instrument soal HOTS ini dikemas dalam bentuk buku yang berisikan kumpulan-kumpulan soal HOTS matematika.

Tahap validasi dan uji coba dilakukan validasi ahli, dalam hal ini divalidasi oleh 2 (dua) dosen Pendidikan matematika dan 2 (dua) guru matematika tingkat SMA dan SMK. Hasil validasi oleh validator tersebut menjadi catatan penting untuk merevisi produk diantaranya; kesesuaian level HOTS, bilangan yang dipilih dalam beberapa soal yang kurang tepat sehingga mempengaruhi jawanban. Dengan catatan validator tersebut dilakukan revisi dengan memperbaiki beberapa instrument soal sesuai dengan indicator level C4,C5, dan C6. Selain itu juga memperbaiki beberapa instrument soal pada pemilihan bilangan yang dipakai dalam soal- soal tersebut supaya menghasilkan jawaban yang pas/ dalam bentuk bilangan bulat. Hasil akhir validasi ahli ditunjukan pada tabel 2.

Tabel. 2. Rekapitulasi Validasi Instrumen Soal HOTS Matematika

\begin{tabular}{lcl}
\hline \multicolumn{1}{c}{ Kategori } & Rerata & \multicolumn{1}{c}{ Keterangan } \\
\hline Ketercakupan Materi & 4,2 & Sangat valid \\
Kesesuaian Level HOTS & 3,8 & Valid \\
Keterbacaan & 4,0 & Sangat valid \\
\hline
\end{tabular}

Dari hasil tabel di atas dapat disimpulkan bahwa instrument soal yang dikembangkan memenuhi kriteria valid dan sangat valid pada masing-masing kategori. Dengan kata lain instrument soal HOTS yang dikembangkan dapat dinyatakan valid dan dapat digunakan sesuai dengan validasi ahli.

Hasil pengembangan Intrumen soal HOTS matematika tersebut diharapkan dapat menunjang kemampuan literasi matematis. Kemampuan literasi matematis merupakan kemampuan individu untuk merumuskan, menerapkan, dan menafsirkan matematika dalam berbagai konteks, yang mencakup penalaran matematis dan kemampuan menggunakan konsep-konsep OECD (2014: 37). Indikator literasi matematis sejatinya berkenaan dengan kemampuan HOTS, analyzing (menganalisis): Memecah materi menjadi bagian-bagian pokok dan mendeskripsikan bagaimana bagian-bagian tersebut 
dihubungkan satu sama lain maupun menjadi sebuah struktur keseluruhan atau tujuan (Kuswana: 2012).

\section{Kesimpulan}

Hasil rata-rata validasi secara konstruk oleh validasi ahli pada pengembangan instrument soal HOTS matematika memenuhi kriteria valid dan sangat valid pada masing-masing kategori. Dengan kata lain instrument soal HOTS yang dikembangkan dapat dinyatakan valid dan dapat digunakan, serta dapat menunjang kemampuan literasi matematis.

\section{Pustaka}

Abidin, Yunus, Tita Mulyati dan Hana Yunansah. 2017. Pembelajaran Literasi: Strategi Meningkatkan Kemampuan Literasi Matematika, Sains, Membaca dan Menulis. Jakarta: Bumi Aksara.

Anderson, L \& Kratwohl, D. R. 2015. Kerangka Landasan Untuk Pembelajaran, Pengajaran, dan Assesment Jogjakarta: Pustaka Belajar

Arifin, Zainal. 2012. Evaluasi Pembelajaran. Bandung: Remaja Rosdakarya.

Asmara, Andes Safarandes, S. B. Waluya dan Rochmad. 2017. "Analisis Kemampuan Literasi Matematika Siswa Kelas X Berdasarkan Kemampuan Matematika". Scholaria. Vol .7 (2). 135-142.

Dewi, Nastitisari. 2016. Analisis Kemampuan Berpikir Kompleks Siswa Melalui Pembelajaran Berbasis Masalah Berbantuan Mind Mapping. Jurnal EduSains.Vol 8 No 1.

Fitrhiyah, A. I. (2018). Pengembangan Perangkat Pembelajaran Matematika Berbasis Warisan Budaya Indonesia untuk Melatihkan Literasi Matematis Siswa. (Skripsi). Universitas Islam Negeri Sunan Ampel Surabaya, Surabaya

Heong, Y. M. 2011. "The Level of Marzano Higher Order Thinking Skills Among Technical Education Students”. International Journal of Social and humanity, Vol. 1,No. 2 .

Kemendikbud. 2018. Rekap Hasil UN Tingkat Sekolah. Diakses dari https://puspendik.kemdikbud.go.id/hasil-un/, Pada 22 Desember 2018.

Kusaeri dan Suprananto. 2012. Pengukuran dan Penilaian Pendidikan. Yogyakarta: Graha Ilmu.

Kusuma, M. D. 2017. "Pengembangan Penilaian Keterampilan Berpikir Tingkat Tinggi (HOTS) Dalam Studi Fisika”. Jurnal Universitas Lampung. Vol 7, hal 32. 
Kuswana, Wowo Sunaryo. 2012. Taksonomi Kognitif. Bandung: PT Remaja Rosdakarya. . 2012. Taksonomi Berpikir. Bandung: PT Remaja Rosdakarya.

. 2012. Pengukuran, Penilaian \& Evaluasi Pendidikan. Yogyakarta:Nuha Medika.

Muliyani dan Huriaty. 2016. Pengembangan Instrumen Tes Geometri dan Pengukuran pada Jenjang SMP. Jurnal Pendidikan Matematika Math Didactic, Vol.2, No.2.

OECD. 2014. PISA 2012 Result: What Students Know and Can Do - Student Performance in Mathematics, Reading and Science (Volume 1). Paris: OECD Publishing.

OECD. 2016. PISA 2015 Results in Focus. Paris: OECD Publishing.

Pamungkas, Aan Subhan. 2017. "Pengembangan Bahan Ajar Berbasis Literasi Pada Materi Bilangan Bagi Mahasiswa Calon Guru SD”. JPSD. Vol. 3 (2). 228-240.

Purwanto. 2013. Evaluasi Hasil Belajar.Yogyakarta: Pustaka Pelajar.

Sari, Rosalia Hera Novita. 2015. “Literasi Matematika: Apa, Mengapa dan Bagaimana?”. Seminar Nasional Matematika dan Pendidikan Matematika UNY 2015. 713-720.

Sukardi. 2012. Evaluasi Pendidikan Prinsip dan Operasionalnya. Jakarta:Bumi Aksara.

Sukmadinata, N.S. 2013, Metode Penelitian Pendidikan. Bandung: PT Remaja Rosdakarya

Uno, Hamzah. 2012. Assesment Pembelajaran. Jakarta: Bumi Aksara.

Wahidmurni, dkk. 2010. Evaluasi Pembelajaran Kompetensi dan Praktik. Yogyakarta: Nuha Litera.

Woolfolk, A. 2008. Educational Psychology Active earn- ing Edition 10th ed. Pearson Education, Inc. 
